Farisa Syeda, Elizabeth Tullis, Arthur S. Slutsky and Haibo Zhang

Am J Physiol Heart Circ Physiol 294:2769-2774, 2008. First published Apr 25, 2008; doi:10.1152/ajpheart.00211.2008

You might find this additional information useful...

This article cites 45 articles, 21 of which you can access free at:

http://ajpheart.physiology.org/cgi/content/full/294/6/H2769\#BIBL

This article has been cited by 1 other HighWire hosted article:

Human neutrophil peptides: a novel potential mediator of inflammatory cardiovascular diseases

K. Quinn, M. Henriques, T. Parker, A. S. Slutsky and H. Zhang

Am J Physiol Heart Circ Physiol, November 1, 2008; 295 (5): H1817-H1824.

[Abstract] [Full Text] [PDF]

Updated information and services including high-resolution figures, can be found at:

http://ajpheart.physiology.org/cgi/content/full/294/6/H2769

Additional material and information about AJP - Heart and Circulatory Physiology can be found at: http://www.the-aps.org/publications/ajpheart

This information is current as of January 20, 2009 .

AJP - Heart and Circulatory Physiology publishes original investigations on the physiology of the heart, blood vessels, and lymphatics, including experimental and theoretical studies of cardiovascular function at all levels of organization ranging from the intact animal to the cellular, subcellular, and molecular levels. It is published 12 times a year (monthly) by the American

Physiological Society, 9650 Rockville Pike, Bethesda MD 20814-3991. Copyright @ 2005 by the American Physiological Society.

ISSN: 0363-6135, ESSN: 1522-1539. Visit our website at http://www.the-aps.org/. 


\title{
Human neutrophil peptides upregulate expression of COX-2 and endothelin-1 by inducing oxidative stress
}

\author{
Farisa Syeda, ${ }^{1,2,3,4}$ Elizabeth Tullis, ${ }^{1,4}$ Arthur S. Slutsky, ${ }^{1,3}$ and Haibo Zhang 1,2,3,4 \\ ${ }^{1}$ The Keenan Research Centre in the Li Ka Shing Knowledge Institute of St. Michael's Hospital; and ${ }^{2}$ Departments \\ of Anaesthesia and Physiology, ${ }^{3}$ Interdepartmental Division of Critical Care Medicine, and ${ }^{4}$ Division of Respiratory \\ Medicine, University of Toronto, Toronto, Ontario, Canada
}

Submitted 28 February 2008; accepted in final form 21 April 2008

Syeda F, Tullis E, Slutsky AS, Zhang H. Human neutrophil peptides upregulate expression of COX-2 and endothelin-1 by inducing oxidative stress. Am J Physiol Heart Circ Physiol 294: H2769-H2774, 2008. First published April 25, 2008; doi:10.1152/ajpheart.00211.2008.-Polymorphonuclear leukocytes (PMNs) play an important role during inflammation in cardiovascular diseases. Human neutrophil peptides (HNPs) are released from PMN granules upon activation and are conventionally involved in microbial killing. Recent studies suggested that HNPs may be involved in the pathogenesis of vascular abnormality by modulating inflammatory responses and vascular tone. Since HNPs directly interact with endothelium upon release from PMNs in the circulation, we tested the hypothesis that the stimulation with HNPs of endothelial cells modulates the expression of vasoactive by-products through altering cyclooxygenase (COX) activity. When human umbilical vein endothelial cells were stimulated with purified HNPs, we observed a time- and dose-dependent increase in the expression of COX-2, whereas COX-1 levels remained unchanged. Despite an increased expression of COX-2 at the protein level, HNPs did not significantly enhance the COX-2 activity, thus the production of the prostaglandin $\mathrm{PGI}_{2}$. HNPs significantly induced the release of endothelin-1 (ET-1) as well as the formation of nitrotyrosine. The HNP-induced COX-2 and ET-1 production was attenuated by the treatment with the oxygen free radical scavenger $\mathrm{N}$-acetyl-L-cysteine and the inhibitors of p38 MAPK and NF- $\mathrm{BB}$, respectively. The angiontensin II pathway did not seem to be involved in the HNP-induced upregulation of COX-2 and ET- 1 since the use of the angiotensin-converting enzyme inhibitor enalapril had no effect in this context. In conclusion, HNP may play an important role in the pathogenesis of inflammatory cardiovascular diseases by activating endothelial cells to produce vasoactive by-products as a result of oxidative stress.

inflammation; immunity; leukocyte

HUMAN NEUTROPHIL PEPTIDES (HNPs), mainly released from polymorphonuclear leukocytes (PMNs) during inflammation, are key players in innate immunity by the upregulation of costimulatory molecules (42), stimulation of cell adhesion (3, 42), release of chemokines $(20,37,41)$, induction of reactive oxygen species (ROS) (31), and T-cell chemotaxis $(4,43)$. In addition, HNPs bind to vascular smooth muscle cells and regulate vascular tone $(25,28)$. Elevated circulating levels of HNPs are found in patients with inflammatory diseases such as acute respiratory distress syndrome and sepsis $(1,30)$, where pulmonary vasoconstriction and systemic vasodilation are frequently implicated.

Address for reprint requests and other correspondence: H. Zhang, Rm. 7-007, Queen Wing, 30 Bond St., Toronto, ON, M5B 1W8, Canada (e-mail: haibo.zhang@utoronto.ca).
The plasma levels of HNPs increase up to $170,000 \mathrm{ng} / \mathrm{ml}$ in patients with sepsis compared with a mean of 42-53 $\mathrm{ng} / \mathrm{ml}$ in the plasma of healthy controls (30). The concentration of HNPs correlates with the number of PMNs in the blood of patients with inflammatory diseases $(1,30)$. The elevated levels of HNP in septic patients suggest that HNPs may play a critical role in the leukocyte-dominant proinflammatory responses that can contribute to cardiovascular disorders $(2,13,27)$.

The vascular endothelium actively participates in maintaining vascular homeostasis by balancing vasoactive compounds between endothelium-derived relaxing and contracting factors. The major vasoactive by-products include prostaglandins, nitric oxide (NO), and endothelin-1 (ET-1).

Prostaglandins are produced following the sequential oxidation of arachidonic acid by cyclooxygenases (COX-1 and $\mathrm{COX}-2$ ) and terminal prostaglandin synthases. COX-1 is responsible for the constitutive levels of prostaglandins, whereas COX-2 produces inducible prostaglandins in scenarios of inflammation through the stimulation of endothelial cells by various growth factors and cytokines (38). The major vasodilatory prostaglandin $\mathrm{E}_{2}\left(\mathrm{PGE}_{2}\right)$ is generated by catalyzing prostaglandin $\mathrm{E}$ synthases on prostaglandin $\mathrm{H}_{2}$ $\left(\mathrm{PGH}_{2}\right)$. Similarly, prostacyclin $\left(\mathrm{PGI}_{2}\right)$ synthase converts $\mathrm{PGH}_{2}$ into $\mathrm{PGI}_{2}$. $\mathrm{PGE}_{2}$ and $\mathrm{PGI}_{2}$ also exert anti-inflammatory properties (44).

ET-1, produced mainly by endothelial cells is a potent vasoconstrictor by interaction with two key receptor types, endothelin receptors types $\mathrm{A}\left(\mathrm{ET}_{\mathrm{A}}\right)$ and $\mathrm{B}\left(\mathrm{ET}_{\mathrm{B}}\right)$. $\mathrm{ET}_{\mathrm{A}}$ receptors are found on the smooth muscle cells of blood vessels, and $\mathrm{ET}_{\mathrm{B}}$ is primarily located on the endothelial cells. Binding of ET-1 to the receptors increases vasoconstriction and the retention of sodium (15). ET-1 is reportedly associated with the pathogenesis of atherosclerosis (11).

It has been recently established that inflammation plays a crucial role in mediating all stages of atherosclerosis from initiation through progression (24). During leukocyte-dominated inflammatory responses, PMNs release large amounts of HNPs into the extracellular milieu. In turn, HNPs stimulate cells to produce ROS (31). The latter is known to modulate the expression of COX-2 and ET- 1 in endothelial cells $(5,17)$. In the present study, we tested and proved the hypothesis that HNP-enhanced expression of COX-2 and ET-1 in endothelial cells through ROS-dependent mechanisms.

The costs of publication of this article were defrayed in part by the payment of page charges. The article must therefore be hereby marked "advertisement" in accordance with 18 U.S.C. Section 1734 solely to indicate this fact. 


\section{METHODS}

Reagents. Anti-COX-1 and COX-2 polyclonal antibodies were purchased from Santa Cruz Biotechnology (Santa Cruz, CA). Monoclonal anti- $\beta$-actin antibodies, $N$-acetyl-L-cysteine (NAC), were obtained from Sigma (St. Louis, MO). Phospho- and total-p38 MAPK antibodies were from Cell Signaling Technology (Danvers, MA), and horseradish peroxidase-conjugated anti-goat and anti-rabbit antibodies were from Jackson ImmunoResearch (West Grove, PA). The selective inhibitors of U-0126 against mitogen-activated protein kinase kinase 1/2 (MEK1/2), SB-203580 against p38 mitogen-activated protein kinase ( $\mathrm{p} 38 \mathrm{MAPK}$ ), and PG-490 (triptolide) and 4-methyl-N1-(3phenylpropyl)benzene-1,2-diamine (JSH-23) against nuclear factor- $\mathrm{KB}$ (NF-кB), respectively, were purchased from Calbiochem (La Jolla, CA). Enhanced chemiluminescence kit was from PerkinElmer (Boston, MA). The purification of HNP has been previously described $(20,42)$.

Cell culture. Human umbilical vein endothelial cells (HUVECs, Cell Applications, San Diego, CA) were cultured in HUVEC medium (Cell Applications) at $37^{\circ} \mathrm{C}$ in a $5 \% \mathrm{CO}_{2}-95 \%$ room air. The cells were used on passage 2.

Western blot analysis. Confluent HUVECs in $30-\mathrm{mm}^{2}$ dishes (Corning Costar, Cambridge, MA) were deprived of serum for 12-16 $\mathrm{h}$ and subjected to HNP stimulation. The cells were then lysed in a buffer containing $63.5 \mathrm{mM}$ Tris $\cdot \mathrm{HCl}(\mathrm{pH} 6.8), 10 \%$ (vol/vol) glycerol, $2 \%$ (wt/vol) SDS, $1 \mathrm{mM} \mathrm{Na} \mathrm{VO}_{4}, 1 \mathrm{mM}$ 4-(2-aminoethyl)benzene sulfonyl fluoride, and $50 \mu \mathrm{g} / \mathrm{ml}$ leupeptin. Cell extracts were subject to SDS-PAGE and transferred to nitrocellulose membrane (Bio-Rad, Hercules, CA). Nonspecific antibody binding was blocked by the incubation of membranes in $50 \mathrm{mM}$ Tris, $150 \mathrm{M} \mathrm{NaCl}$, and $0.02 \%$ (vol $/ \mathrm{vol}$ ) Tween 20, pH 7.4 (TBST), containing 5\% milk for $2 \mathrm{~h}$. Membranes were subsequently incubated with the appropriate primary antibody in TBST/10\% BSA. After being extensively washed with TBST, membranes were incubated with horseradish peroxidaseconjugated secondary antibodies. Membranes were washed and signals were visualized with an enhanced chemiluminescence detection system (ECL Kit; PerkinElmer). The band density was determined by a Kodak image station 2000 MM (Mandel Scientific, Guelph, ON, Canada).

Measurement of $\mathrm{PGI}_{2}, P G E_{2}$, and ET-1. Upon completion of the experiments, the cell culture medium was collected and centrifuged at $112 \mathrm{~g}$ for $5 \mathrm{~min}$. The cell culture supernatants were assayed for 6-ketoPGF- $1 \alpha$, a stable intermediate of $\mathrm{PGI}_{2}$, using an ELISA kit (GE Healthcare, Buckinghamshire, UK). Levels of $\mathrm{PGE}_{2}$ (GE Healthcare) and ET-1 were measured by ELISA kits (R\&D Systems, Minneapolis, MN).

Nitrotyrosine assay. Nitrotyrosine levels were detected in cell culture supernatants by using a commercial kit (Bioxytech Nitrotyrosine-EIA, Oxis International, Portland, OR).

Cytotoxicity measurement. To confirm the excellent cell viability in the conditions where HNP and/or the inhibitors were present, lactate dehydrogenase activity was measured at $490 \mathrm{~nm}$ (Cytotoxicity detection kit, Roche Applied Science, Penzberg, Germany) in all experiments.

Statistical analysis. Data are presented as means \pm SD. Data were analyzed in nonparametric tests by using Prism GraphPad 4.0 software package (Prism, San Diego, CA). A comparison among groups was performed by ANOVA using the Kruskal-Wallis test. A $P<0.05$ was considered as significant.

\section{RESULTS}

HNPs increased the expression of $C O X-2$ by the activation of p38 MAPK, ERK $1 / 2$, and $N F-\kappa B$. HUVECs $\left(1 \times 10^{6}\right.$ cells $)$ were stimulated with HNPs at 5 and $25 \mu \mathrm{g} / \mathrm{ml}$ for 4,6 , and $8 \mathrm{~h}$, respectively. The cell viability measured by lactate dehydrogenase assays was not changed at the doses of HNPs used compared with the vehicle control group over time (data not shown). A time- and dose-dependent increase in COX-2 expression was observed, whereas the expression of COX-1 remained unchanged in response to HNP stimulation (Fig. 1A).
Fig. 1. Human neutrophil peptides (HNPs) increased expression of cyclooxygenase (COX)-2 by activation of $\mathrm{p} 38$ MAPK, ERK1/2, and NF-кB. A: confluent human umbilical vein endothelial cell (HUVEC) monolayers were incubated overnight with serum-free medium and exposed to either $0.01 \%$ acetic acid as vehicle control or HNPs. $B$ and $C$ : cells were treated with either vehicle (DMSO alone), SB-203580 $(10 \mu \mathrm{M}), \mathrm{U}-0126(10 \mu \mathrm{M}), 4$-methyl-N1-(3phenylpropyl)benzene-1,2-diamine (JSH-23; $10 \mu \mathrm{M}$ ), or PG-490 $(70 \mathrm{nM})$ for $30 \mathrm{~min}$ before stimulation with HNPs $(25 \mu \mathrm{g} / \mathrm{ml})$ for additional $6 \mathrm{~h}$. Cells were lysed for Western blot analysis. Representative blots are illustrated from 3 independent experiments. The bar graphs present densitometric analysis of 3 experiments. $* P<0.05$ vs. vehicle controls, respectively; $\dagger P<0.05$ vs. the immediate previous group; and $\ddagger P<0.05$ vs. HNPs alone at identical conditions, respectively.
A
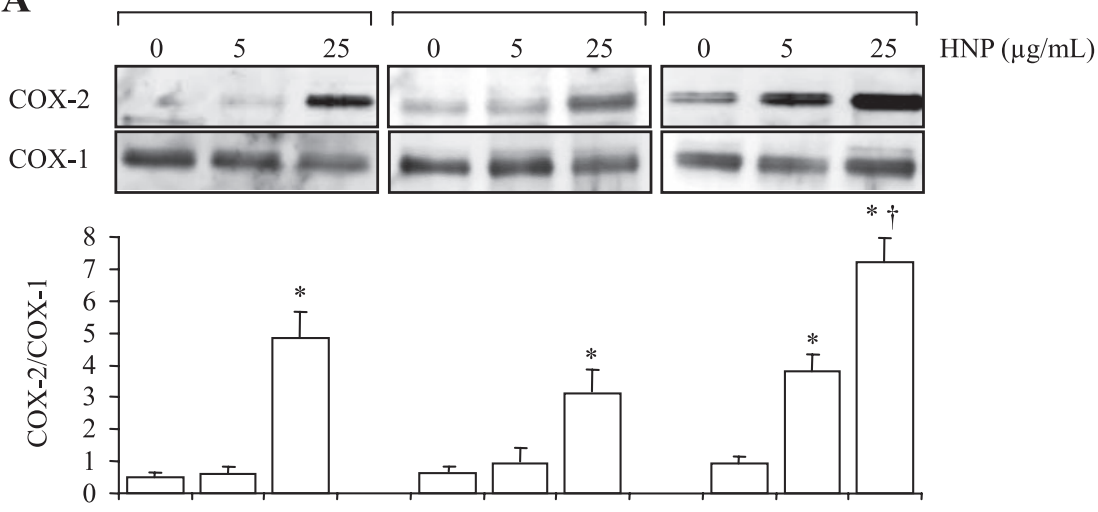

\section{B}
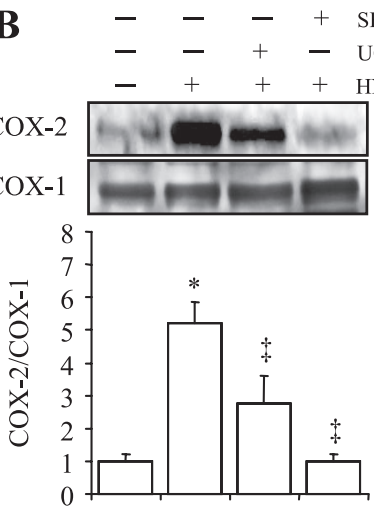

C

$\mathrm{C} \quad-\quad-\quad+$ JSH-23 $0126 \quad-\quad-\quad+\quad-\quad$ PG-490 P $(25 \mu \mathrm{g} / \mathrm{mL})$
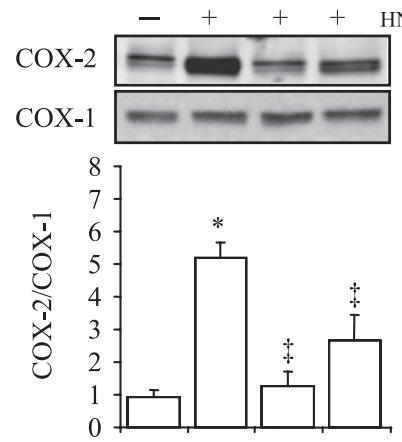
We next showed that the HNP-induced COX-2 expression was completely blocked by the inhibition of p38 MAPK and largely attenuated by the inhibition of MEK $1 / 2$ at the dose used (Fig. $1 B$ ). Since COX-2 expression is possibly mediated by NF-кB (8) and since we have previously demonstrated that the stimulation of epithelial and $\mathrm{CD} 4^{+} \mathrm{T}$ cells with HNP induced

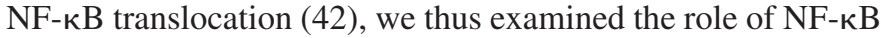
on the HNP-induced COX-2 expression by using the inhibitors JSH-23 and PG-490 (Triptolide) in HUVECs. The two compounds have been widely used as NF- $\mathrm{\kappa B}$ inhibitors in in vivo and in vitro conditions $(6,8,34,36)$. We observed a significant attenuation of the HNP-induced COX-2 expression by using the NF- $\mathrm{BB}$ inhibitors (Fig. 1C).

HNPs had no significant effects on COX-2 activity and production of $\mathrm{PGI}_{2}$. Production of $\mathrm{PGE}_{2}$ has been used as an index of COX-2 activity (12). The COX-2 activity was not significantly altered after $\mathrm{HNP}$ stimulation although the level of $\mathrm{PGI}_{2}$ tended to increase in the cell culture medium (Fig. 2, $A$ and $B$ ). We
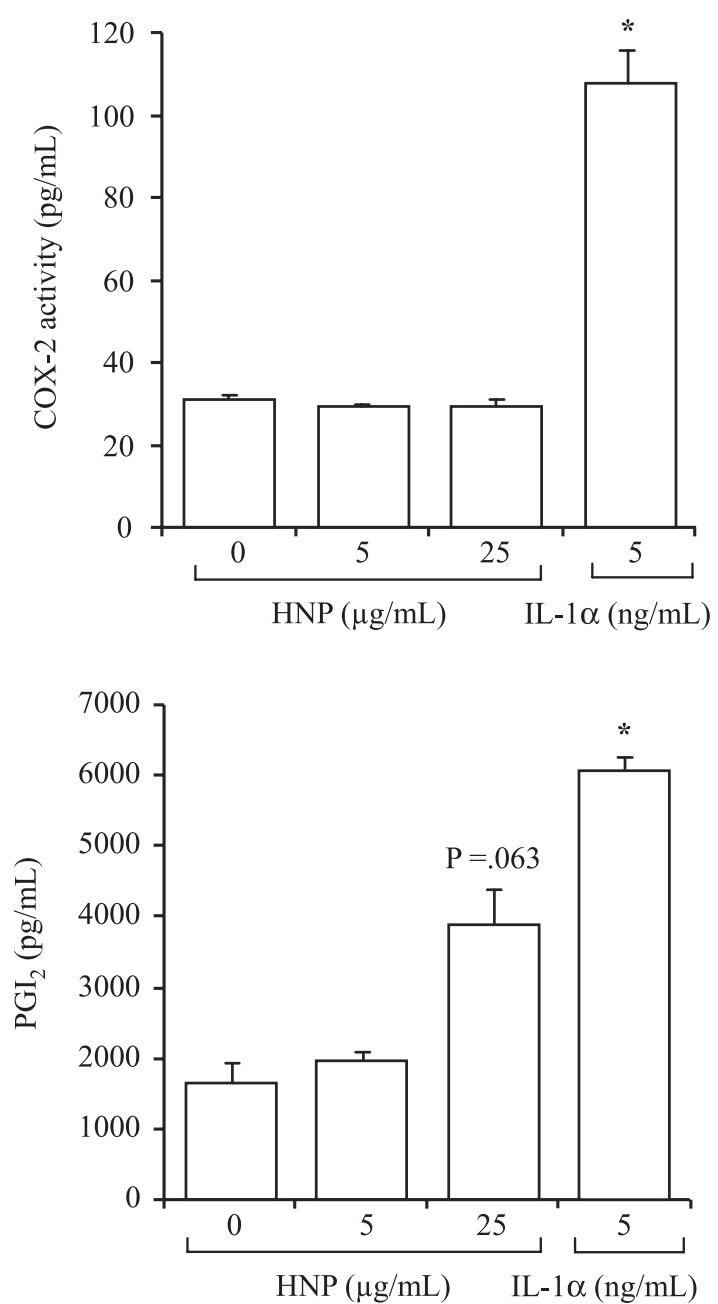

Fig. 2. HNPs had no significant effects on COX-2 activity (top) and prostacyclin $\left(\mathrm{PGI}_{2} ;\right.$ bottom). Confluent HUVEC monolayers were incubated overnight with serum-free medium and exposed to either $0.01 \%$ acetic acid as vehicle control (0) or indicated concentrations of HNPs for $6 \mathrm{~h}$. COX-2 activity and concentration of $\mathrm{PGI}_{2}$ in cell supernatants was measured. IL- $1 \alpha$ was used as a positive control for the COX-2 activity and $\mathrm{PGI}_{2}$ production. $N=3$ experiments. ${ }^{*} P<0.05$ vs. vehicle control at identical conditions, respectively.
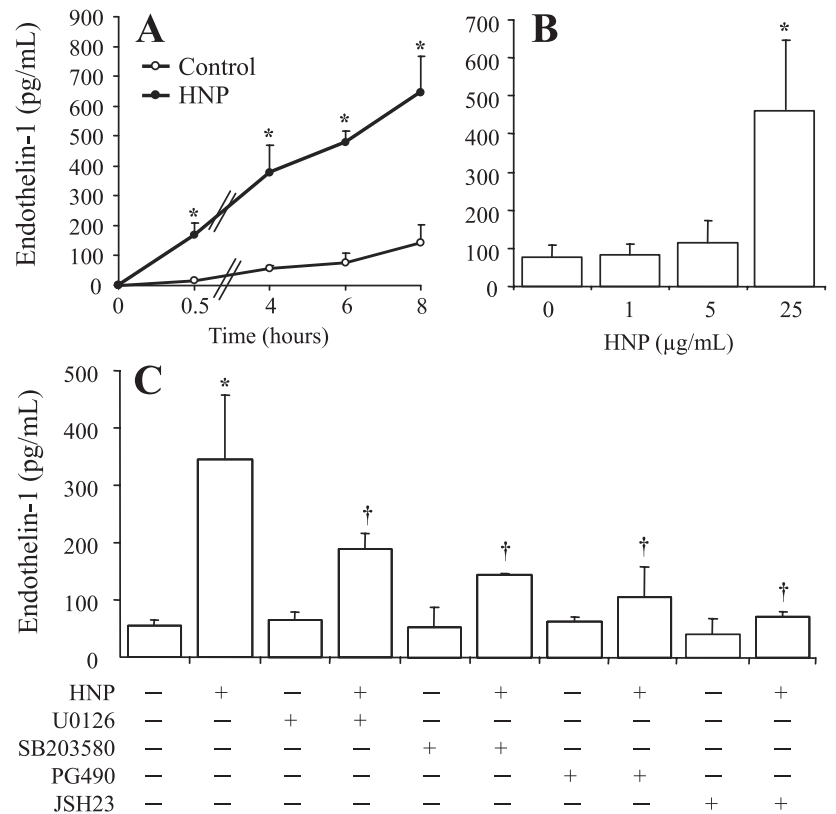

Fig. 3. HNPs increased endothelin-1 (ET-1) release by activation of p38 MAPK, ERK1/2, and NF-кB. A: time-dependent increase in ET-1. HUVECs were stimulated with HNPs $(25 \mu \mathrm{g} / \mathrm{ml})$ or vehicle control $(0.01 \%$ acetic acid $)$ for the indicated times. Concentration of ET-1 was measured in the cell supernatants. $B$ : dose-dependent increase in ET-1. HUVECs were treated with indicated doses of HNPs for $6 \mathrm{~h}$. $C$ : cells were pretreated with either vehicle (DMSO alone), U-0126 $(10 \mu \mathrm{M})$, SB-203580 $(10 \mu \mathrm{M})$, PG-490 $(70 \mathrm{nM})$, or JSH-23 $(10 \mu \mathrm{M})$ for $30 \mathrm{~min}$ before stimulation with HNPs $(25 \mu \mathrm{g} / \mathrm{ml})$ for additional 6 h. $N=3$ experiments. $* P<0.05$ vs. vehicle control at identical conditions, respectively. $\dagger P<0.05$ vs. HNPs alone.

also stimulated the cells with IL-1 $\alpha$ as a positive control (9) to ensure that the cells were able to increase COX-2 activity and the production of $\mathrm{PGI}_{2}$ (Fig. 2, $A$ and $B$ ).

HNPs increased ET-1 release by activation of p38 MAPK, $E R K 1 / 2$, and $N F-\kappa B$. Since ET-1 is a major vasoconstrictor produced by endothelium, we measured the concentration of ET-1 that is produced independent of the COX-2 pathway. We observed a significant increase in ET-1 release as early as 30 min, followed by a time-dependent increase in response to HNP stimulation at a dose of $25 \mu \mathrm{g} / \mathrm{ml}$ (Fig. 3A). Stimulation with HNPs at a dose lower than $25 \mu \mathrm{g} / \mathrm{ml}$ for $8 \mathrm{~h}$ had no effects on ET-1 production (Fig. $3 B$ ). The HNP-induced ET-1 expression was significantly reduced by the use of inhibitors against p38 MAPK, ERK1/2, and NF-кB, respectively (Fig. 3C).

HNPs induced COX-2 and ET-1 through oxidative stress. ROS have been reported as key mediators to induce production of COX-2 $(5,17)$ and ET-1 $(5,18)$. We have previously reported that HNPs stimulate lung tissue to produce hydrogen peroxide (31). We thus measured the concentration of nitrotyrosine in HUVEC culture medium after HNP stimulation. Nitrotyrosine is a marker of peroxynitrite formation as a result of the generation of $\mathrm{NO}$ and superoxide (16). We observed that the stimulation of HUVECs with HNPs at $25 \mu \mathrm{g} / \mathrm{ml}$ resulted in a fourfold and 2.5-fold increase in nitrotyrosine levels at 30 min and $4 \mathrm{~h}$, respectively (Fig. 4). When the antioxidant NAC was used to inhibit the HNP-induced oxidative stress, we observed a decrease in the expression of both COX-2 and ET-1 (Fig. 5, $A$ and $B$ ) associated with an attenuation of p38 MAPK phosphorylation (Fig. $5 C$ ). Taken together, these results sug- 


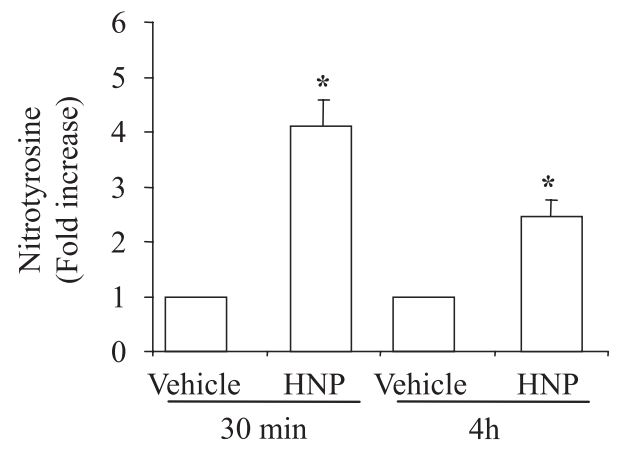

Fig. 4. HNPs induced nitrotyrosine formation in HUVECs. Confluent HUVEC monolayers were incubated overnight with serum-free medium and exposed to either $0.01 \%$ acetic acid as vehicle control or HNPs $(25 \mu \mathrm{g} / \mathrm{ml})$ for the indicated times. Nitrotyrosine levels in cell supernatants were measured by ELISA. $N=3$ experiments. $* P<0.05$ vs. vehicle control.

gest that the HNPs induced an increase in the expression of COX-2 and ET-1 through oxidative stress.

HNPs had no effects on angiontensin II to modulate COX-2 and ET-1. A large body of evidence supports a role of angiontensin II in the modulation of the expression of COX-2 and ET-1 $(5,17,40)$. We thus examined the angiontensin II pathway in the HNP-induced expression of COX-2 and ET-1 by using the dicarboxylate-containing angiotensin-converting enzyme inhibitor enalapril. Our results showed no effects on the HNP-induced expression of COX-2 or ET-1 by using enalapril at a dose of $100 \mu \mathrm{M}$ (Fig. 6, $A$ and $B$ ).

\section{DISCUSSION}

A main finding of our study is that HNPs can stimulate human endothelial cells to increase the expression of COX-2 and ET-1, and ROS play an important role in mediating the HNP-induced activation of endothelial cells. The treatment of endothelial cells with the ROS scavenger NAC attenuated the elevated expression of COX-2 and ET-1 in response to HNP stimulation.

Previous in vivo and in vitro studies have described the role of ROS and peroxynitrite in the regulation of COX-2 expression $(21,22)$. We have demonstrated that exposure of lung
A

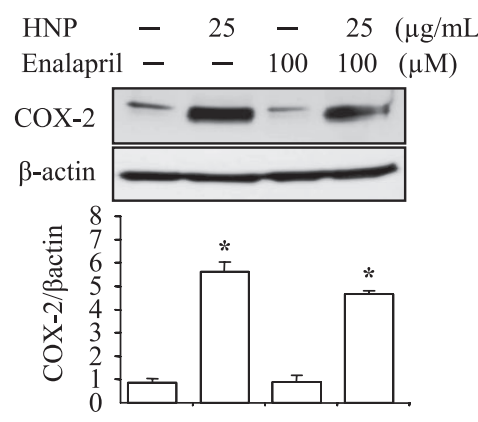

Fig. 6. HNPs had no effects on angiontensin II to modulate COX-2 and ET-1. $A$ : HUVECs were incubated with enalapril for $30 \mathrm{~min}$ before stimulation with HNPs for additional $6 \mathrm{~h}$. COX-2 expression was detected by Western blot analysis. $B$ : concentration of ET-1 was measured in cell supernatant by ELISA. $N=3$ experiments. ${ }^{*} P<0.05$ vs. vehicle $(0.01 \%$ acetic acid $)$ control, respectively.

explants to HNPs resulted in an increase in the hydrogen peroxide production (31). We now observe an increased formation of nitrotyrosine that reflects the interaction between NO and ROS by human endothelial cells in response to HNP stimulation. Furthermore, the HNP-induced COX-2 expression was attenuated by the treatment with NAC. This observation indicates that HNPs increased COX-2 expression through oxidative stress. Previous studies have reported that an upregulation of COX-2 after stimulation with cytokines, thrombin, and growth factors usually led to an increased production of $\mathrm{PGI}_{2}$ in HUVECs $(29,36)$. However, the production of the prostaglandins $\mathrm{PGI}_{2}$ and $\mathrm{PGE}_{2}$ was not significantly altered despite an elevated COX-2 expression after HNP stimulation in our study. Interestingly, previous studies have also reported an absence of prostaglandin release despite an elevated COX-2 expression following the stimulation with $\mathrm{NO}$ donors $(10,32)$. A couple of mechanisms may explain the paradox of an increased COX-2 expression with the lack of prostaglandin production. Peroxynitrite can cause tyrosine nitration of COX, leading to the inactivation of COX activity (39). Peroxynitrite can also act as a potent inhibitor of PGI synthase, a terminal enzyme in $\mathrm{PGI}_{2}$ biosynthesis (7). It is noteworthy that we
$\mathbf{A}$

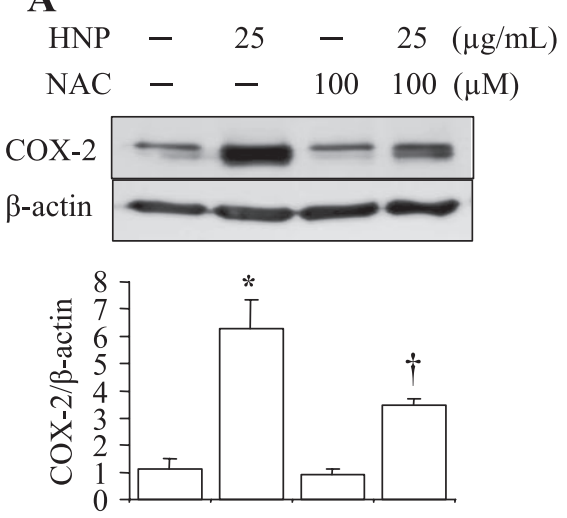

B

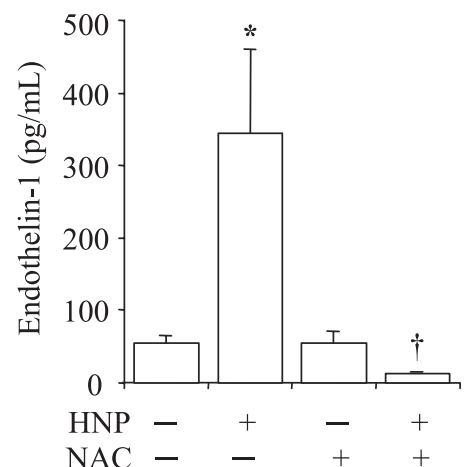

C

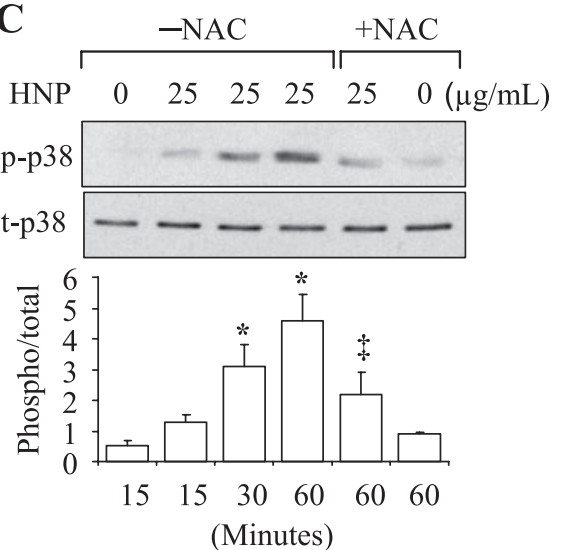

Fig. 5. HNPs upregulated COX-2 and ET-1 through oxidative stress. HUVECs were pretreated with $N$-acetyl-L-cysteine (NAC) 30 min before exposure to HNPs for additional $6 \mathrm{~h}$. Cell lysates were analyzed by Western blot analysis for COX-2 protein. A: representative immunoblot is shown from 3 separate experiments. $B$ : ET-1 released in cell supernatants was assayed by ELISA. $C$ : HUVECs were pretreated with NAC 30 min before exposure to HNPs for the indicated times. The cell lysates were analyzed for phosphorylated (p) and total (t) levels of p38 by Western blot analysis. $N=3$ experiments. $* P<0.05$ vs. vehicle control; $\dagger P<0.05$ vs. HNPs alone, respectively; $\ddagger P<0.05$ vs. HNPs alone at 30 and 60 min, respectively. 
examined only $\mathrm{PGI}_{2}$ and $\mathrm{PGE}_{2}$ because they are the most characterized prostaglandins. The effects of HNP on other prostaglandins remain yet to be determined.

ET-1 is a dominant vasoconstrictor produced by endothelial cells $(19,26)$. We observed a rapid increase in ET-1 release as early as 30 min after HNP stimulation in HUVECs. The early and sustained expression of ET-1 could be due to autocrine regulatory properties by which ET-1 acts on cell surface receptors that in turn activates cells releasing more ET-1 (26). In addition, the HNP-induced oxidative stress at $30 \mathrm{~min}$, as reflected by the formation of nitrotyrosine, resulted in the production of ET-1 that was blocked by the treatment of the cells with NAC. Our results are consistent with other studies reporting that ROS play an important role to stimulate smooth muscle cells (18) and endothelial cells (19), producing ET-1 in in vitro and in vivo conditions $(14,45)$. It is noteworthy that the level of ET-1 expression in the NAC-treated group following HNP stimulation is somewhat lower than the nonstimulated or the NAC alone groups. This might suggest that some factors other than the ROS-dependent mechanism play a partial role in the HNP-induced ET-1 expression.

To understand the intracellular signaling mechanisms by which HNPs upregulated the expression of COX-2 and ET-1, we examined several signaling pathways including p38 MAPK, ERK1/2, and NF-кB since we have previously demonstrated that the kinases and NF- $\mathrm{KB}$ are involved in the modulation of adhesion molecules and IL- 8 by monocytes and $\mathrm{CD}^{+}$cells in response to HNP stimulation $(37,42)$. By employing the specific inhibitors, we observed that p38 MAPK, ERK1/2, and NF-кB signaling pathways are required to modulate the HNP-induced expression of COX-2 and ET-1 in HUVECs. Other studies have demonstrated that the kinases and NF- $\mathrm{KB}$ signaling are required in the regulation of $\mathrm{COX}-2$ and ET-1 in response to a variety of stimuli $(23,35)$.

The release of ET-1 was increased as short as $30 \mathrm{~min}$, whereas COX-2 expression was upregulated at $4 \mathrm{~h}$ or later after HNP stimulation. In addition, the inhibitors of kinases and $\mathrm{NF}-\kappa \mathrm{B}$ were involved in the expression of ET-1 and COX-2. Taken together, these observations suggests that the early release of ET-1 may be responsible for the late increased COX-2 expression, which is consistent with a study demonstrating that the activation of p38 MAPK is involved in endothelin-1-stimulated COX-2 expression in cultured esophageal smooth muscle cells (35).

It has been suggested that angiontensin II modulates COX-2 and ET-1 expression $(5,17)$. We did not observe any significant effects of the angiontensin-II pathway on the HNPinduced COX-2 or ET-1 expression in HUVECs by using enalapril, an inhibitor of angiotensin-converting enzyme. Unlike other angiotensin-converting enzyme inhibitors, enalapril does not interfere with the NO and ROS pathways (33). Taken together, these studies further support the central role of ROS by which HNPs activate endothelial cells.

In summary, we demonstrate that HNPs increased COX-2 and ET-1 expression in endothelial cells via ROS-dependent mechanisms associated with the activation of p38 MAPK, ERK1/2, and NF- $\kappa$ B signaling pathways. The effects of HNPs in the modulation of the course of cardiovascular diseases are yet to be elucidated in in vivo conditions.

\section{ACKNOWLEDGMENTS}

F. Syeda is a recipient of Keenan Collaborative Project Fellowship of St. Michael's Hospital. H. Zhang is a recipient of Ontario Premier's Research Excellence Award.

\section{GRANTS}

This study was supported by Canadian Institutes of Health Research Grants CIHRMOP8558 and MOP69042 (to A. S. Slutsky and H. Zhang) and an Ontario Thoracic Society grant-in-aid (to H. Zhang).

\section{REFERENCES}

1. Ashitani J, Mukae H, Arimura Y, Sano A, Tokojima M, Nakazato M. High concentrations of alpha-defensins in plasma and bronchoalveolar lavage fluid of patients with acute respiratory distress syndrome. Life Sci 75: 1123-1134, 2004.

2. Barnathan ES, Raghunath PN, Tomaszewski JE, Ganz T, Cines DB, Higazi A. al-R. Immunohistochemical localization of defensin in human coronary vessels. Am J Pathol 150: 1009-1020, 1997.

3. Chaly YV, Paleolog EM, Kolesnikova TS, Tikhonov II, Petratchenko EV, Voitenok NN. Neutrophil alpha-defensin human neutrophil peptide modulates cytokine production in human monocytes and adhesion molecule expression in endothelial cells. Eur Cytokine Netw 11: 257-266, 2000.

4. Chertov O, Michiel DF, Xu L, Wang JM, Tani K, Murphy WJ, Longo DL, Taub DD, Oppenheim JJ. Identification of defensin-1, defensin-2, and CAP37/azurocidin as T-cell chemoattractant proteins released from interleukin-8-stimulated neutrophils. J Biol Chem 271: 2935-2940, 1996.

5. Cingolani HE, Villa-Abrille MC, Cornelli M, Nolly A, Ennis IL, Garciarena C, Suburo AM, Torbidoni V, Correa MV, Camilionde Hurtado MC, Aiello EA. The positive inotropic effect of angiotensin II: role of endothelin-1 and reactive oxygen species. Hypertension 47: 727 734, 2006.

6. Corson TW, Crews CM. Molecular understanding and modern application of traditional medicines: triumphs and trials. Cell 130: 769-774, 2007.

7. Cosentino F, Eto M, De Paolis P, van der Loo B, Bachschmid M, Ullrich V, Kouroedov A, Delli Gatti C, Joch H, Volpe M, Luscher TF. High glucose causes upregulation of cyclooxygenase-2 and alters prostanoid profile in human endothelial cells: role of protein kinase $\mathrm{C}$ and reactive oxygen species. Circulation 107: 1017-1023, 2003.

8. Dai YQ, Jin DZ, Zhu XZ, Lei DL. Triptolide inhibits COX-2 expression via NF-kappa B pathway in astrocytes. Neurosci Res 55: 154-160, 2006.

9. Dianzani C, Collino M, Gallicchio M, Di Braccio M, Roma G, Fantozzi R. Effects of anti-inflammatory [1, 2, 4]triazolo[4, 3-a] [1, 8]naphthyridine derivatives on human stimulated PMN and endothelial cells: an in vitro study. J Inflamm (Lond) 3: 4, 2006.

10. Eligini S, Habib A, Lebret M, Creminon C, Levy-Toledano S, Maclouf J. Induction of cyclo-oxygenase-2 in human endothelial cells by SIN-1 in the absence of prostaglandin production. Br J Pharmacol 133: 1163-1171, 2001.

11. Fan J, Unoki H, Iwasa S, Watanabe T. Role of Endothelin-1 in atherosclerosis. Ann NY Acad Sci 902: 84-94, 2000.

12. Giuliano F, Warner TD. Ex vivo assay to determine the cyclooxygenase selectivity of non-steroidal anti-inflammatory drugs. Br J Pharmacol 126: 1824-1830, 1999.

13. Higazi AA, Lavi E, Bdeir K, Ulrich AM, Jamieson DG, Rader DJ, Usher DC, Kane W, Ganz T, Cines DB. Defensin stimulates the binding of lipoprotein (a) to human vascular endothelial and smooth muscle cells. Blood 89: 4290-4298, 1997.

14. Hink U, Munzel T. COX-2, another important player in the nitric oxide-endothelin cross-talk: good news for COX-2 inhibitors? Circ Res 98: 1344-1346, 2006.

15. Humbert M, Sitbon O, Simonneau G. Treatment of pulmonary arterial hypertension. $N$ Engl J Med 351: 1425-1436, 2004.

16. Hurst JK. Whence nitrotyrosine? J Clin Invest 109: 1287-1289, 2002.

17. Jaimes EA, Tian RX, Pearse D, Raij L. Up-regulation of glomerular COX-2 by angiotensin II: role of reactive oxygen species. Kidney Int 68 : 2143-2153, 2005.

18. Kahler J, Ewert A, Weckmuller J, Stobbe S, Mittmann C, Koster R, Paul M, Meinertz T, Munzel T. Oxidative stress increases endothelin-1 synthesis in human coronary artery smooth muscle cells. J Cardiovasc Pharmacol 38: 49-57, 2001. 
19. Kahler J, Mendel S, Weckmuller J, Orzechowski HD, Mittmann C, Koster R, Paul M, Meinertz T, Munzel T. Oxidative stress increases synthesis of big endothelin-1 by activation of the endothelin-1 promoter. J Mol Cell Cardiol 32: 1429-1437, 2000.

20. Khine AA, Del Sorbo L, Vaschetto R, Voglis S, Tullis E, Slutsky AS, Downey GP, Zhang H. Human neutrophil peptides induce interleukin-8 production through the P2Y6 signaling pathway. Blood 107: 2936-2942, 2006.

21. Kim SF, Huri DA, Snyder SH. Inducible nitric oxide synthase binds, S-nitrosylates, and activates cyclooxygenase-2. Science 310: 1966-1970, 2005.

22. Landino LM, Crews BC, Timmons MD, Morrow JD, Marnett LJ. Peroxynitrite, the coupling product of nitric oxide and superoxide, activates prostaglandin biosynthesis. Proc Natl Acad Sci USA 93: 1506915074, 1996.

23. Lee HM, Won KJ, Kim J, Park HJ, Kim HJ, Roh HY, Lee SH, Lee CK, Kim B. Endothelin-1 induces contraction via a Syk-mediated p38 mitogen-activated protein kinase pathway in rat aortic smooth muscle. J Pharm Sci 103: 427-433, 2007.

24. Libby P, Aikawa M, Jain MK. Vascular endothelium and atherosclerosis. Handb Exp Pharmacol 176: 285-306, 2006.

25. Lopez-Bermejo A, Chico-Julia B, Castro A, Recasens M, Esteve E, Biarnes J, Casamitjana R, Ricart W, Fernandez-Real JM. Alpha defensins 1, 2, and 3: potential roles in dyslipidemia and vascular dysfunction in humans. Arterioscler Thromb Vasc Biol 27: 1166-1171, 2007.

26. Murakoshi N, Miyauchi T, Kakinuma Y, Ohuchi T, Goto K, Yanagisawa M, Yamaguchi I. Vascular endothelin-B receptor system in vivo plays a favorable inhibitory role in vascular remodeling after injury revealed by endothelin-B receptor-knockout mice. Circulation 106: 1991-1998, 2002.

27. Nassar H, Lavi E, Akkawi S, Bdeir K, Heyman SN, Raghunath PN, Tomaszewski J, Higazi AA. $\alpha$-Defensin: link between inflammation and atherosclerosis. Atherosclerosis 194: 452-457, 2007.

28. Nassar T, Akkawi S, Bar-Shavit R, Haj-Yehia A, Bdeir K, Al-Mehdi AB, Tarshis M, Higazi AA. Human alpha-defensin regulates smooth muscle cell contraction: a role for low-density lipoprotein receptor-related protein/alpha 2-macroglobulin receptor. Blood 100: 4026-4032, 2002.

29. Olszanecki R, Gebska A, Korbut R. Production of prostacyclin and prostaglandin E2 in resting and IL-1beta-stimulated A549, HUVEC and hybrid EA.HY 926 cells. J Physiol Pharmacol 57: 649-660, 2006.

30. Panyutich AV, Panyutich EA, Krapivin VA, Baturevich EA, Ganz T. Plasma defensin concentrations are elevated in patients with septicemia or bacterial meningitis. J Lab Clin Med 122: 202-207, 1993.

31. Porro GA, Lee JH, de Azavedo J, Crandall I, Whitehead T, Tullis E, Ganz T, Liu M, Slutsky AS, Zhang H. Direct and indirect bacterial killing functions of neutrophil defensins in lung explants. Am J Physiol Lung Cell Mol Physiol 281: L1240-L1247, 2001.

32. Reddy ST, Herschman HR. Prostaglandin synthase-1 and prostaglandin synthase-2 are coupled to distinct phospholipases for the generation of prostaglandin D2 in activated mast cells. J Biol Chem 272: 3231-3237, 1997.

33. Scribner AW, Loscalzo J, Napoli C. The effect of angiotensin-converting enzyme inhibition on endothelial function and oxidant stress. Eur J Pharmacol 482: 95-99, 2003.

34. Shin HM, Kim MH, Kim BH, Jung SH, Kim YS, Park HJ, Hong JT, Min KR, Kim Y. Inhibitory action of novel aromatic diamine compound on lipopolysaccharide-induced nuclear translocation of NF-kappaB without affecting IkappaB degradation. FEBS Lett 571: 50-54, 2004.

35. Song HJ, Min YS, Shin CY, Jeong JH, Sohn UD. Activation of p38 MAPK is involved in endothelin-1-stimulated COX-2 expression in cultured Feline esophageal smooth muscle cells. Mol Cells 22: 44-50, 2006.

36. Syeda F, Grosjean J, Houliston RA, Keogh RJ, Carter TD, Paleolog E, Wheeler-Jones CP. Cyclooxygenase-2 induction and prostacyclin release by protease-activated receptors in endothelial cells require cooperation between mitogen-activated protein kinase and NF-kappaB pathways. J Biol Chem 281: 11792-11804, 2006.

37. Syeda F, Liu HY, Tullis E, Liu M, Slutsky AS, Zhang H. Differential signaling mechanisms of HNP-induced IL-8 production in human lung epithelial cells and monocytes. J Cell Physiol 214: 820-827, 2008.

38. Tsatsanis C, Androulidaki A, Venihaki M, Margioris AN. Signalling networks regulating cyclooxygenase-2. Int J Biochem Cell Biol 38: $1654-$ 1661, 2006.

39. Upmacis RK, Deeb RS, Hajjar DP. Oxidative alterations of cyclooxygenase during atherogenesis. Prostaglandins Other Lipid Mediat 80: 1-14, 2006.

40. Ushio-Fukai M, Alexander RW, Akers M, Griendling KK. p38 Mitogen-activated protein kinase is a critical component of the redox-sensitive signaling pathways activated by angiotensin II. Role in vascular smooth muscle cell hypertrophy. J Biol Chem 273: 15022-15029, 1998.

41. Van Wetering S, Mannesse-Lazeroms SP, Van Sterkenburg MA, Daha MR, Dijkman JH, Hiemstra PS. Effect of defensins on interleukin-8 synthesis in airway epithelial cells. Am J Physiol Lung Cell Mol Physiol 272: L888-L896, 1997.

42. Vaschetto R, Grinstein J, Del Sorbo L, Khine AA, Voglis S, Tullis E, Slutsky AS, Zhang H. Role of human neutrophil peptides in the initial interaction between lung epithelial cells and CD4+ lymphocytes. J Leukoc Biol 81: 1022-1031, 2007.

43. Yang D, Chen Q, Chertov O, Oppenheim JJ. Human neutrophil defensins selectively chemoattract naive $\mathrm{T}$ and immature dendritic cells. J Leukoc Biol 68: 9-14, 2000.

44. Yin H, Cheng L, Langenbach R, Ju C. Prostaglandin $I_{2}$ and $E_{2}$ mediate the protective effects of cyclooxygenase-2 in a mouse model of immunemediated liver injury. Hepatology 45: 159-69, 2007.

45. Zhou Y, Mitra S, Varadharaj S, Parinandi N, Zweier JL, Flavahan NA. Increased expression of cyclooxygenase-2 mediates enhanced contraction to endothelin $\mathrm{ET}_{\mathrm{A}}$ receptor stimulation in endothelial nitric oxide synthase knockout mice. Circ Res 98: 1439-1445, 2006. 